\title{
Review
}

\section{Human Urotensin II as a Link between Hypertension and Coronary Artery Disease}

\author{
Takuya WATANABE ${ }^{1)}$, Tomoko KANOME ${ }^{1)}$, Akira MIYAZAKI ${ }^{1}$, and Takashi KATAGIRI ${ }^{2}$
}

\begin{abstract}
Hypertension is a well-known risk factor for atherosclerosis, but the molecular mechanisms that link elevated blood pressure to the progression of atherosclerosis remain unclear. Human urotensin II (U-II), the most potent endogenous vasoconstrictor peptide identified to date, and its receptor (UT receptor) are involved in the etiology of essential hypertension. In patients with essential hypertension, U-II infused into the forearm brachial artery has been shown to induce vasoconstriction. Recent studies have demonstrated elevated plasma U-II concentrations in patients with essential hypertension, diabetes mellitus, atherosclerosis, and coronary artery disease. U-II is expressed in endothelial cells, macrophages, macrophage-derived foam cells, and myointimal and medial vascular smooth muscle cells (VSMCs) of atherosclerotic human coronary arteries. UT receptors are present in VSMCs of human coronary arteries, the thoracic aorta and cardiac myocytes. Lymphocytes are the most active producers of U-II, whereas monocytes and macrophages are the major cell types expressing UT receptors, with relatively little receptor expression in foam cells, lymphocytes, and platelets. U-II accelerates foam cell formation by up-regulation of acyl-coenzyme A:cholesterol acyltransferase-1 in human monocyte-derived macrophages. In human endothelial cells, U-II promotes cell proliferation and up-regulates type 1 collagen expression. U-II also activates nicotinamide adenine dinucleotide phosphate (NADPH) oxidase and plasminogen activator inhibitor-1 in human VSMCs, and stimulates VSMC proliferation with synergistic effects observed when combined with oxidized low-density lipoprotein, lysophosphatidylcholine, reactive oxygen species or serotonin. These findings suggest that UII plays key roles in accelerating the development of atherosclerosis, thereby leading to coronary artery disease. (Hypertens Res 2006; 29: 375-387)
\end{abstract}

Key Words: urotensin II, hypertension, atherosclerosis, metabolic syndrome, coronary artery disease

\section{Introduction}

The vascular effects of elevated blood pressure promote atherothrombotic disease, with consequences for cardiac, cerebral, and renal dysfunction. Hypertension is one of the most important risk factors of coronary artery disease, and is diagnosed in approximately $50 \%$ of patients with acute myocardial infarction. Large epidemiological studies, such as the Framingham Heart Study, have shown that increasing systolic or diastolic blood pressure increases the likelihood of coro- nary events and mortality from coronary artery disease (1). The Cardiovascular Health Study confirmed a linear relationship between risk of cardiovascular disease and blood pressure in subjects $\geq 65$ years of age (2). Similarly, the Multiple Risk Factor Intervention Trial (MRFIT) found a significant increase in the relative risk of coronary heart disease with increased blood pressure in men in a younger cohort (aged 35-47) (3).

Hypertension is a well-known risk factor for atherosclerosis. Increased systolic blood pressure has been shown to be associated with increased intima-media thickness (IMT) in

From the ${ }^{1)}$ Department of Biochemistry and ${ }^{2}$ Third Department of Internal Medicine, Showa University School of Medicine, Tokyo, Japan.

Portions of the authors' work reviewed in this paper were supported by a Grant from the Showa University School of Medicine Alumni Association.

Address for Reprints: Takuya Watanabe, M.D., Ph.D., Department of Biochemistry, Showa University School of Medicine, 1-5-8 Hatanodai, Shinagawa-ku, Tokyo 142-8555, Japan. E-mail: watanabemd@med.showa-u.ac.jp

Received December 26, 2005; Accepted in revised form March 10, 2006. 


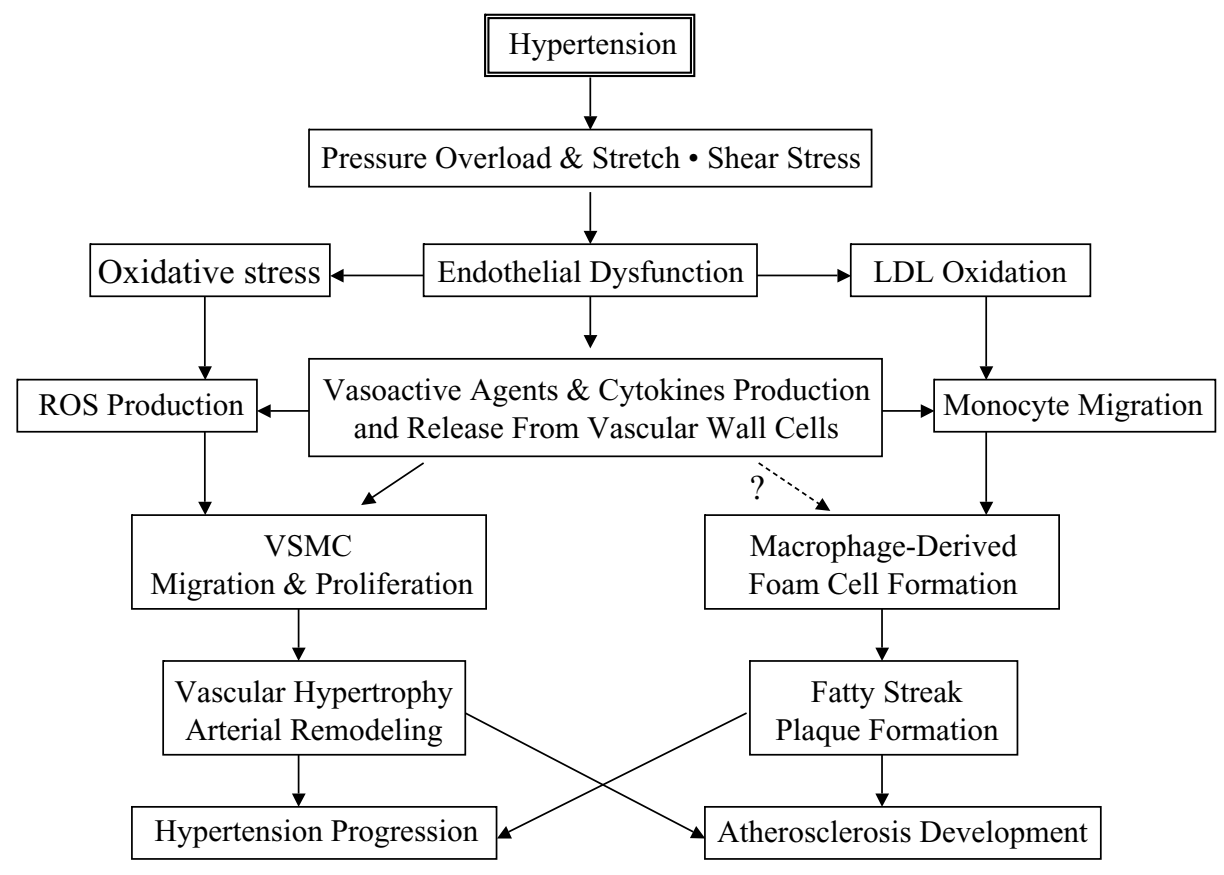

Fig. 1. Relationships among hypertension, vascular remodeling, and atherosclerosis. ROS, reactive oxygen species; LDL, lowdensity lipoprotein; VSMC, vascular smooth muscle cell.

the common carotid artery, an early clinical measure of preatherosclerotic changes (4). Hypertension has been shown to stimulate the development of aortic atherosclerosis in animal models of dyslipidemia. For example, in the Watanabe Heritable Hyperlipidemic (WHHL) rabbit, which has hypercholesterolemia due to a genetic defect in the low-density lipoprotein (LDL) receptor, experimental renovascular hypertension caused a marked increase in lesion area and the severity of lesions in the aorta (5). Similarly, New Zealand White rabbits fed an atherogenic diet showed increased adhesion of monocytes to the aorta when blood pressure was increased by aortic coarctation (6).

Hypertension is associated with increases in the prevalence of both early and advanced atherosclerosis, both of which are characterized by vascular smooth muscle cell (VSMC) hyperplasia and extracellular matrix synthesis. There have been a number of proposals regarding the mechanism underlying the potentiation of atherosclerosis by hypertension, but the mechanism is still unclear. Several investigators have suggested that it may be related to pressure overload and increased stretch or shear stress on the artery wall (Fig. 1). In the presence of acute and severe hypertension, shear-induced injury of the wall through endothelial injury may elicit a proliferative response of underlying VSMCs. With chronic hypertension, endothelial denudation is usually not observed, but endothelial dysfunction is prevalent (7), including direct mechanical disruptive effects, actions on vasoactive agents and cytokines, effects of sodium influx, changes in blood rheology, and alterations in vascular wall composition. Another major contributor may be increased transport of LDL into the vessel wall, together with reduced efflux to the circulation (8). In animal models of hypertension, there is also lower oxygen tension in the inner $40 \%$ of the artery wall despite the lack of a difference in the partial pressure of oxygen in arterial blood (9). This hypoxia may lead to reactive oxygen species (ROS) production and tissue damage, which in turn may amplify the atherogenic potential of the increased level of LDL infiltration (10). Oxidative stress converts LDL to oxidized LDL in the artery wall. This oxidized LDL interacts with vasoactive agents, such as angiotensin II, endothelin-1, and serotonin, in the induction of VSMC hyperplasia (11).

There are two specific vascular growth-related abnormalities induced by hypertension-hypertrophic remodeling and atherosclerosis (Fig. 1) - which appear to be similar pathological lesions but which have quite different anatomical distributions and compositions. Hypertrophic remodeling involves increases in cell number (hyperplasia), cell size (hypertrophy), and deposition of fibrillar or nonfibrillar extracellular matrix, or various combinations of these effects, in the media of almost all of the arterial tree. Thickening of the arterial media probably occurs secondary to increased wall tension, leading to progression of hypertension. Atherosclerosis involves the lipid core, known as the atheroma, in the intima of large and medium-sized arteries. The initial pathological alterations, called fatty streaks, which are visible on the endothelial surface of the arteries, are composed of lipid deposition in the macrophages (foam cells). The bulk of the deposited lipid is composed of cholesterol and cholesterol 


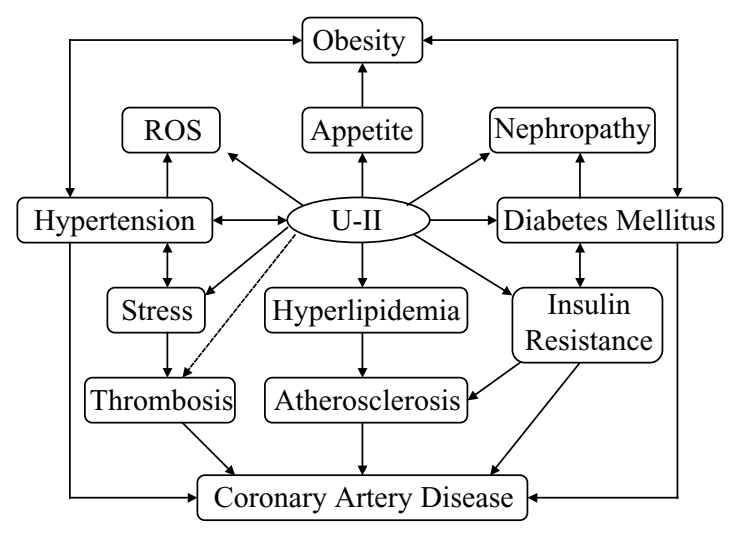

Fig. 2. Roles of urotensin II (U-II) in the metabolic syndrome. ROS, reactive oxygen species.

ester. Whether they progress to advanced lesions, so-called fibrous plaques, is dependent on hemodynamic forces, such as hypertension and the plasma levels of atherogenic lipoproteins, such as oxidized LDL. Fibrous plaques appear first in the abdominal aorta, coronary arteries, and carotid arteries. However, the molecular mechanisms that link hypertension to the development and progression of atherosclerosis remain unclear.

In linking a predisposition for atherosclerosis with hypertension, it is important to consider not only the mechanical effects of elevated intra-arterial pressure, but also the cluster of clinical characteristics known as the metabolic syndrome. Decreased insulin sensitivity is characteristic of essential hypertension, even in non-obese subjects, and is further aggravated by obesity, especially visceral adiposity. In the metabolic syndrome, insulin resistance may contribute to hypertension and a predisposition to develop type 2 diabetes mellitus, which is also associated with an abnormal lipid profile. Each of these characteristics is atherogenic and can augment cardiovascular disease risk (12). Oxidative stress is also closely associated with hypertension and atherosclerosis (13). Hozawa et al. (14) have shown increased plasma levels of 8isoprostane as a marker of systemic oxidative stress in hypertension. Plasma levels of autoantibodies raised against oxidized LDL, which were used as an index of LDL oxidation, as well as oxidized LDL itself were shown to be elevated in patients with essential hypertension as compared with normotensive controls $(15,16)$. In addition, major contributors to blood pressure control include the sympathetic nervous system and the renin-angiotensin-aldosterone system. Dysregulation of either of these systems contributes to hypertension and can promote atherosclerosis.

There have been a number of recent studies of the effects of various vasoactive agents in both hypertension and atherogenesis. In particular, human urotensin II (U-II), the most potent mammalian vasoconstrictor identified to date (17), may play a key role in the pathogenesis of atherosclerosis, not only through its hemodynamic effects but also through direct cellular and molecular actions on the vessel wall. Some important processes of atherogenesis are known to be enhanced by U-II. Recently, we demonstrated a novel role of U-II in fatty streak formation, which is the first step of the development of atherosclerotic lesions characterized by accumulation of lipid-laden macrophages. In our previous studies, the atherogenic properties of U-II were demonstrated by accelerated foam cell formation in human monocyte-derived macrophages (18) and by the mitogenic and synergistic effects of U-II with some mitogens, such as oxidized LDL, lysophosphatidylcholine, ROS, and serotonin in VSMCs (19, 20).

Accumulating lines of evidence have shown that U-II is closely linked to the metabolic syndrome (21) (Fig. 2). Studies in human subjects have demonstrated increased levels of plasma and urinary U-II in hypertensive patients or type 2 diabetic patients (22-25). Moreover, certain polymorphisms in the U-II gene ( $89 \mathrm{~N}$ allele) have been associated with development of type 2 diabetes via insulin resistance in the Japanese population (26). Tubular epithelial cells obtained at nephrectomy from patients with diabetic nephropathy showed overexpression of U-II and UT receptor (27). In the presence of diabetes mellitus, U-II may also be associated with obesity (28). Intracerebroventricular administration of U-II into sheep causes hyperglycemia, which may be mediated by UII-stimulated increases in circulating levels of epinephrine and cortisol (29). In perfused rat pancreas models, U-II has inhibited insulin release in response to glucose (30). U-II also stimulates hyperlipidemia in fish by enhancing triglyceride lipase activity and channeling glucose to free fatty acid synthesis (31).

In this review, we will provide an overview of U-II and its specific receptor, the UT receptor, in the vasculature, with a focus on the vasoconstrictive and atherogenic effects of U-II and their underlying cellular mechanisms. We will also discuss emerging evidence suggesting a pathophysiological role of U-II in coronary artery disease, and therapeutics for U-II mediated cardiovascular disease.

\section{U-II and UT Receptor System}

Human U-II is a cyclic undecapeptide of 11 amino acids (HGlu-Thr-Pro-Asp-c[Cys-Phe-Trp-Lys-Tyr-Cys]-Val-OH) containing a disulfide bridge between $\mathrm{Cys}^{5}$ and $\mathrm{Cys}^{10}$ (Fig. 3), with a molecular weight of $\sim 1,388$ (32). This peptide, isolated originally from fish urophysis (a neurosecretory organ of the caudal spinal cord), is derived from pre-pro U-II, which consists of 124 and 139 amino acid residues, by urotensinconverting enzyme (33). U-II has been identified as an endogenous ligand for the G-protein coupled receptor 14 (GPR14)/ sensory epithelia neuropeptide-like receptor (SENR) orphan receptor, with seven transmembrane domains, which was cloned recently and renamed the UT receptor (34). The U-II and UT receptor genes are located on human chromosomes 


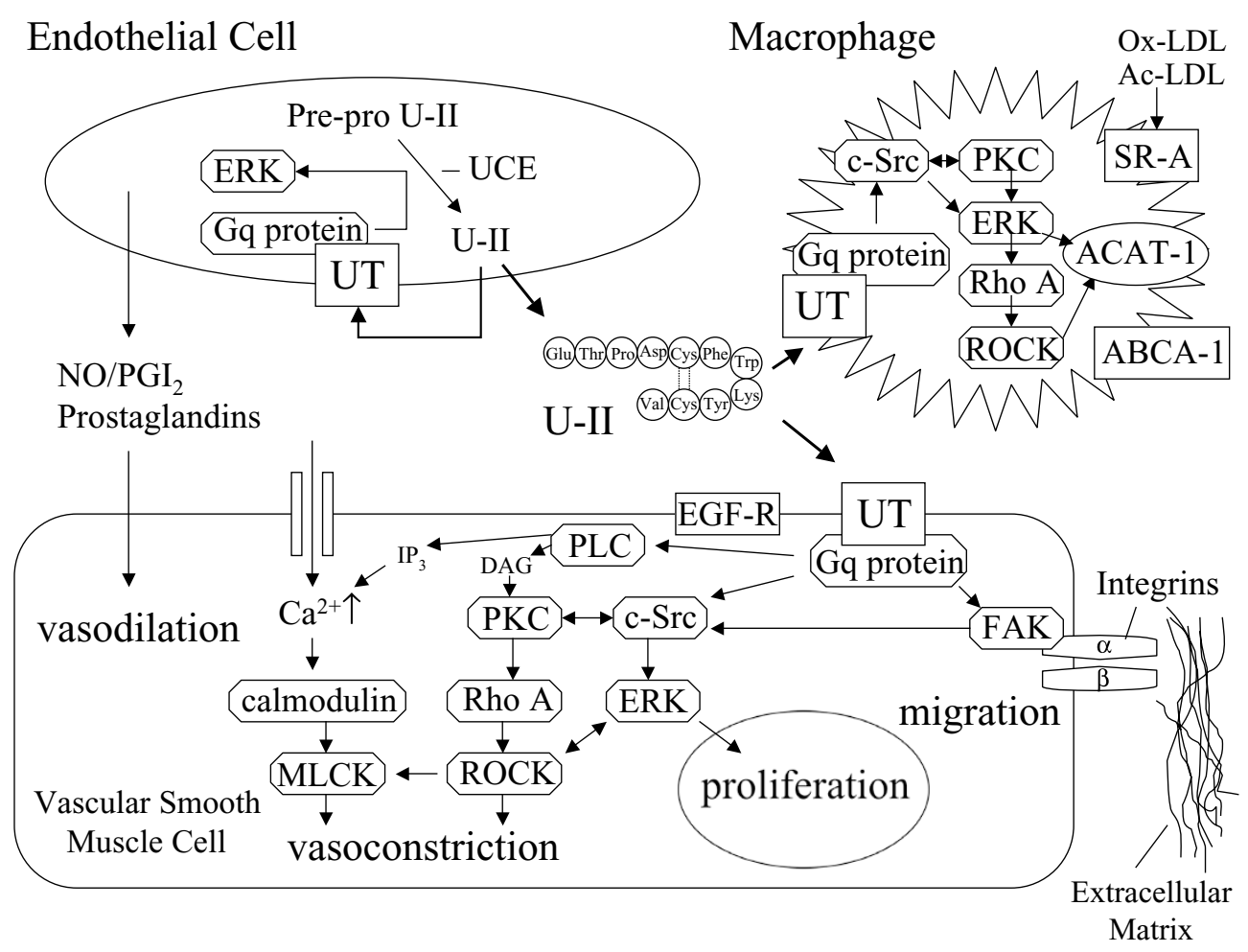

Fig. 3. Intracellular signal transduction pathways in urotensin II (U-II)-induced vascular responses. UT, urotensin II receptor; UCE, urotensin-converting enzyme; ox-LDL, oxidized low-density lipoprotein; ac-LDL, acetylated low-density lipoprotein; SRA, scavenger receptor class A; ACAT-1, acyl-coenzyme A:cholesterol acyltransferase-1; ABCA-1, adenosine triphosphate-binding cassette transporter A-1; PKC, protein kinase C; ERK, extracellular signal-regulated kinase; ROCK, Rho kinase; EGF-R, epidermal growth factor receptor; PLC, phospholipase $C$; IP, inositol-1,4,5-trisphosphate; DAG, diacylglycerol; FAK, focal adhesion kinase; $M L C K$, myosin light chain kinase; $P G I_{2}$, prostacyclin; $N O$, nitric oxide.

$1 \mathrm{p} 36-\mathrm{p} 32$ and $17 \mathrm{q} 25.3$, respectively $(26,35)$. Both the U-II and UT receptor are expressed ubiquitously in different tissues, including the heart, brain, kidney, VSMCs, endothelium, and regions of monocyte/macrophage infiltration in atherosclerotic plaques of the coronary and carotid arteries and abdominal aortic aneurysms $(32,36-38)$. The strength ranking of U-II mRNA expression is kidney $>$ right atrium $>$ interventricular septum $>$ right auricle $>$ blood vessels (including both arteries and veins) (39). Among vessels, U-II levels are highest in the aorta, followed in order by the femoral artery and pulmonary artery, suggesting production in the pulmonary vasculature or the aorta with clearance of U-II in the systemic microcirculation (40). In contrast, UT receptor mRNA is expressed equally and abundantly in both cardiovascular and renal tissues (39). The levels of expression of UII and UT receptor are up-regulated by the inflammatory mediators such as interleukin- 6 and $1 \beta(41)$ and interferon- $\gamma$ (42) and may be down-regulated by the sympathetic nervous system, atrial natriuretic peptide (ANP), or brain natriuretic peptide (BNP) $(43,44)$.

U-II circulates in human plasma, and its main sources are the heart, liver, and kidney (45). Plasma concentrations of U-
II average from 2 to $20 \mathrm{pmol} / 1$ in healthy volunteers (39) (Table 1), and are increased in essential hypertension (22), severe coronary artery disease (46), ischemic cardiomyopathy (47), congestive heart failure (48), diabetes mellitus (24), renal failure (49), portal hypertension caused by liver cirrhosis (50), and eclampsia (51). In patients with congestive heart failure, U-II is positively correlated with endothelin-1, ANP, and BNP (52). Evidence reported by Douglas and colleagues $(17,32,34,38,43)$ indicates that U-II is the most potent endogenous vasoconstrictor identified to date, with a potency 1-2 orders of magnitude greater than that of endothelin-1, and that it is an important contributor to cardiovascular diseases.

\section{U-II and Vasoconstriction}

In mammals, U-II was first reported to have a vasoconstrictor action in isolated rat thoracic aorta denuded of endothelium (53). However, the vasoconstrictor action of U-II has not been found to be universal. Inconsistent responses have been found between species and between different regions of the vasculature within a species. In particular, attention has been focused on the fact that U-II produces both endothelium-independent 
Table 1. Plasma Concentrations (pmol/l) of Urotensin II in Health and Disease

\begin{tabular}{|c|c|c|c|c|c|c|c|c|c|}
\hline & Control & HT & CAD & $\begin{array}{c}\text { Ischemic } \\
\text { cardiomyopathy }\end{array}$ & $\mathrm{CHF}$ & $\mathrm{DM}$ & $\mathrm{RF}$ & $\begin{array}{c}\text { Portal } \\
\text { hypertension }\end{array}$ & Eclampsia \\
\hline Wilkinson et al. (73) & $12 \pm 3$ & & & & & & & & \\
\hline Affolter et al. (74) & $16 \pm 1$ & & & & & & & & \\
\hline Cheung et al. (22) & $8.8 \pm 0.9$ & $14 \pm 1.4 *$ & & & & & & & \\
\hline Heringlake et al. (46) & $1,015 \pm 650$ & & $1,511 \pm 886^{*}$ & & & & & & \\
\hline Russell et al. (40) & $20 \pm 9$ & & & $224 \pm 87^{\dagger}$ & & & & & \\
\hline Lapp et al. (47) & $1,357 \pm 463$ & & & $3,474 \pm 521 *$ & & & & & \\
\hline Richards et al. (39) & $1.9 \pm 0.9$ & & & & $3.9 \pm 1.4^{\dagger}$ & & & & \\
\hline \multirow[t]{2}{*}{$\mathrm{Ng}$ et al. $(48)$} & 6.6 & & & & 22 & & & & \\
\hline & $(3.1-42.6)$ & & & & $(3.1-49.2)$ & & & & \\
\hline Totsune et al. (24) & $4.4 \pm 0.2$ & & & & & $7.8 \pm 0.6^{\dagger}$ & & & \\
\hline Totsune et al. (49) & $4.4 \pm 1.0$ & & & & & & $13 \pm 3^{\dagger}$ & & \\
\hline \multirow[t]{2}{*}{ Heller et al. (50) } & 2,594 & & & & & & & 8,862 & \\
\hline & $(72-8,646)$ & & & & & & & $(1,153-29,827)^{\dagger}$ & \\
\hline Balat et al. (51) & $2.8 \pm 1.2$ & & & & & & & & $7.3 \pm 4.3^{\dagger}$ \\
\hline
\end{tabular}

HT, hypertension; CAD, coronary artery disease; CHF, chronic heart failure; DM, diabetes mellitus; RF, renal failure. Mean \pm SD. ${ }^{*} p<0.01,{ }^{\dagger} p<0.0001 v$ s. each control.

vasoconstriction and endothelium-dependent vasodilatation, as does endothelin-1 (36). U-II induced endothelium-dependent vasodilatation in rat coronary arteries, and this effect was attenuated by removal of the endothelium (54). U-II caused vasoconstriction in endothelium-denuded coronary arteries from various species, including rats, cynomolgus monkeys, dogs, and humans (55-57). This response is attributed to direct activation of UT receptors (17), and is supported most compellingly by the absence of U-II contractile activity in UT receptor knockout mice (58).

In function studies using human vessels, U-II is a potent, low-efficacy vasoconstrictor of most human arteries and veins tested and is likely to contribute to vascular tone (57). $\mathrm{U}-\mathrm{II}$ is the most potent vasoconstrictor identified to date, with approximately 10-fold, 100-fold, and 300-fold greater potency than endothelin-1, serotonin, and norepinephrine, respectively, in human right atrial muscles (59). U-II causes vasoconstriction in the human coronary, mammary, radial and main pulmonary arteries, and saphenous and umbilical veins in vitro $(57,60)$. However, a contractile response to UII was not detected in some human small resistance vessels ( $\leq 250 \mu \mathrm{m}$ internal diameter), including small pulmonary resistance arteries, abdominal resistance vessels, and small subcutaneous arteries and veins (61-63). The vascular effects of U-II are variable with respect to responses obtained from strains, vascular beds, and regions from the same vascular bed within the same species other than different species (64).

U-II-mediated vasoconstriction is mediated via UT receptors in VSMCs $(17,65)$ (Fig. 3). Binding of U-II to UT receptors leads to $\mathrm{Gq}$ protein activation, which leads to activation of protein kinase $\mathrm{C}$ ( $\mathrm{PKC}$ ), protein tyrosine kinase, calmodulin, and phospholipase C (PLC), as evidenced by the inhibition of vasoconstriction by specific inhibitors of these enzymes (66-68). PLC leads to the production of arachidonate second messengers, inositol-1,4,5-triphosphate $\left(\mathrm{IP}_{3}\right) /$ diacylglycerol (DAG), which was demonstrated by an increase in $\left[{ }^{3} \mathrm{H}\right]$ inositol-phosphate when aortic tissue was stimulated with U-II. The activation of these messengers leads to release of $\mathrm{Ca}^{2+}$ from the sarcoplasmic reticulum, which in turn stimulates extracellular $\mathrm{Ca}^{2+}$ influx leading to vasoconstriction, which can be blocked by extracellular $\mathrm{Ca}^{2+}$ channel blockers. In addition to $\mathrm{Ca}^{2+}$-calmodulin-dependent myosin light chain kinase (MLCK), the vasoconstrictive effects of U-II are also mediated in part by the extracellular signal-regulated kinase (ERK) and RhoA/Rho kinase (ROCK)-related pathways (69) (Fig. 3). In contrast, U-II has been demonstrated to be an endothelium-dependent vasodilator, acting through release of nitric oxide (NO), prostacyclin $\left(\mathrm{PGI}_{2}\right)$, prostaglandin $\mathrm{E}_{2}$, or endothelium-derived hyperpolarizing factor $(36,70,71)$ (Fig. $3)$. Therefore, these findings suggest that U-II contributes to the modulation of vascular homeostasis.

Bohm and Pernow (72) reported that infusion of U-II into the brachial artery caused vasoconstriction in vivo in healthy humans, while Wilkinson et al. (73) reported that infusion of U-II had no effect on vasoconstriction. The reason for this apparent discrepancy is unknown, but may reflect the variability in responsiveness reported in previous in vitro studies using preparations from different patients. Similar protocols were adopted in the two studies, including measurement of forearm blood flow by venous occlusion plethysmography in the non-dominant arm of male subjects at rest in the supine position, and the infusion of increasing doses of U-II up to $300 \mathrm{pmol} / \mathrm{min}$. Unlike the study of Bohm and Pernow (72), which recruited $\sim 24$-year-old subjects with the exclusion criterion of a history of smoking, the subjects participating in the study by Wilkinson and colleagues $(73,74)$ were obviously 
Table 2. Effects of Urotensin II on Vascular Wall Cells in Atherosclerosis

\begin{tabular}{|c|c|}
\hline \multicolumn{2}{|l|}{ Endothelial cells } \\
\hline Permeability $\uparrow$ & Gendron et al. 2004 (87) \\
\hline Proliferation $\uparrow$ & Shi et al. $2005(88)$ \\
\hline Collagen-1个 & Wang et al. 2004 (89) \\
\hline 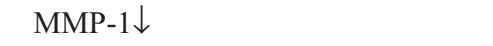 & Wang et al. 2004 (89) \\
\hline \multicolumn{2}{|l|}{ Macrophages } \\
\hline Foam cell formation $\uparrow$ & Watanabe et al. 2005 (18) \\
\hline ACAT-1个 & Watanabe et al. 2005 (18) \\
\hline $\mathrm{SR}-\mathrm{A} \rightarrow$ & Watanabe et al. 2005 (18) \\
\hline $\mathrm{ABCA}-1 \rightarrow$ & Watanabe et al. (unpublished data) \\
\hline \multicolumn{2}{|l|}{ Vascular smooth muscle cells } \\
\hline Contraction $\uparrow$ & Ames et al. 1999 (17), Sauzeau et al. 2001 (69) \\
\hline Endothelium-dependent relaxation $\downarrow$ & Bottrill et al. 2000 (55) \\
\hline Proliferation $\uparrow$ & Watanabe et al. $2001(19,20)$ \\
\hline NADPH $\uparrow$ & Djordjevic et al. 2005 (96) \\
\hline PAI- $1 \uparrow$ & Djordjevic et al. 2005 (96) \\
\hline F-actin $\uparrow$, G-actin $\downarrow$ & Sauzeau et al. 2001 (69) \\
\hline $\mathrm{FAK} \uparrow$ & Peng et al. $2000(95)$ \\
\hline \multicolumn{2}{|l|}{ Fibroblasts } \\
\hline Collagen synthesis $\uparrow$ & Tzanidis et al. 2003 (104) \\
\hline
\end{tabular}

MMP-1, matrix metalloproteinase-1; ACAT-1, acyl-coenzyme A:cholesterol acyltransferase-1; SR-A, scavenger receptor class A; ABCA-1, adenosine triphoshate-binding cassette transporter A-1; NADPH, nicotinamide adenine dinucleotide phosphate; PAI-1, plasminogen activator inhibitor-1; FAK, focal adhesion kinase.

older ( 42 years), and did not appear to be excluded based on a history of smoking. The source of U-II also differed between the two studies. In patients with essential hypertension, administration of U-II caused a dose-dependent vasoconstrictor response in the forearm skin microcirculation (75). It is likely that enhanced contractility to U-II is associated with endothelial dysfunction due to hypertension (64).

\section{U-II and Hypertension}

A recent study by Behm et al. (76) described a "classical systemic hypertensive response" to U-II following i.v. infusion in cats. U-II caused hypertension and tachycardia when injected into the rat lateral cerebroventricle, and these effects were inhibited by pentolinium, indicating a direct contribution of the sympathetic nervous system $(77,78)$. Cardiovascular responses, such as hypertension, tachycardia, and positive inotropy, were observed following intracerebroventricular injection of U-II into sheep (29) - in this study, elevated plasma concentrations of epinephrine and adrenocorticotropic hormone were detected, consistent with U-II-dependent increased sympathetic nerve activity to the adrenal medulla. Pressor and tachycardiac responses were also observed after infusion of U-II into regions containing the arcuate and paraventricular nuclei (79). Increased plasma levels of U-II were observed in spontaneously hypertensive rats (SHR), and in an in utero protein restriction model of hypertension, as compared with normotensive control Wistar-Kyoto rats, sug- gesting up-regulation (80).

A small case-control study by Thompson et al. (81) did not find significant differences in either plasma or cerebrospinal fluid levels of U-II between 10 patients receiving long-term treatment for essential hypertension and 10 age-matched normotensive controls, although there was a positive correlation between U-II level in the cerebrospinal fluid and mean arterial pressure. However, Cheung et al. (22) recently showed that plasma concentrations of U-II were elevated in 62 hypertensive patients (37 taking antihypertensive medication) as compared with 62 age-matched normotensive controls (Table 1) and showed positive correlations with systolic and diastolic blood pressure. In this hypertensive cohort, plasma U-II concentrations were independent of antihypertensive therapy. Rdzanek et al. (82) showed that plasma U-II concentration was increased further with treadmill exercise (workload: $\sim 6.5$ metabolic equivalents [METs]) in hypertensive patients with prior myocardial infarction than in normotensive patients with prior myocardial infarction $(53.3 \pm 35.0$ to $70.6 \pm 29.2$ $\mathrm{pmol} / \mathrm{l} v \mathrm{~s} .39 .6 \pm 27.5$ to $45.6 \pm 26.0 \mathrm{pmol} / \mathrm{l})$. Levels of urinary excretion of U-II were significantly higher in patients with essential hypertension than in normotensive controls, and in patients with hypertension and renal disease than in normotensive patients with renal disease (23). A recent study by Liu et al. (83) showed that the U-II/UT receptor system is associated with pheochromocytoma. These findings suggest that the $\mathrm{U}-\mathrm{II} / \mathrm{UT}$ receptor system may be involved in the etiology of hypertension. 


\section{$\mathrm{U}-\mathrm{Il}$ and Atherosclerosis and Restenosis}

Our unpublished observations indicated that plasma U-II concentrations were significantly increased in 50 patients with essential hypertension as compared with 31 normotensive volunteers (7.9 \pm 7.6 vs. $2.3 \pm 1.2 \mathrm{pmol} / 1, p<0.0001)$. In the total of 81 subjects in our study, plasma U-II concentrations showed significant positive correlations with systolic blood pressure, carotid IMT, plaque score, and homeostasis model assessment for insulin resistance (HOMA-IR). Multiple logistic regression analysis revealed that U-II concentration was associated with a 1.6-fold higher risk of carotid plaque formation (plaque score $\geq 1.1$ ) as compared with the well established risk factors, such as age, systolic blood pressure, serum concentrations of small dense LDL, high-sensitivity Creactive protein, and HOMA-IR. The unpublished data from our other study indicated that plasma U-II concentrations $(3.2 \pm 1.2$ vs. $2.2 \pm 1.4 \mathrm{pmol} / 1, p<0.01)$ as well as carotid plaque prevalence were significantly increased in 30 patients with vascular dementia caused by stroke or atherothrombotic cerebrovascular disease (84), as compared with 30 agematched controls. Bousette et al. (38) showed that both U-II and UT receptor are highly expressed in human carotid plaque. Rakowski and colleagues (85) reported recently that U-II plays an important role in the pathogenesis of restenosis following balloon angioplasty in rat carotid arteries. The expression of UT receptor in the aorta was significantly higher in atherogenic apolipoprotein $\mathrm{E}^{-/-}$knockout mice than in wild-type controls, suggesting that UT receptor up-regulation is a proatherogenic factor in the pathogenesis of atherosclerosis $(86)$.

\section{U-II and Vascular Wall Cells and Platelets}

Atherosclerosis is generally associated with endothelial cell injury and/or dysfunction, resulting in lipid and leukocyte deposition in the arterial wall. Endothelial cells as well as macrophages in the intimal layer release growth factors that induce VSMC proliferation and VSMC migration from the media to the intima. The accumulation of lipids, foam cells, myointimal cells, and extracellular matrix proteins in the subendothelial layer will lead to the formation of atherosclerotic plaques. Recent studies showed that U-II plays a role in the development and progression of atherosclerosis by stimulating proliferation of endothelial cells and VSMCs and fibroblast-mediated collagen deposition (Table 2). Endothelial cells are the first line of vascular wall cells to be damaged in atherosclerosis. U-II increases endothelial cell permeability in the rat thoracic aorta (87). U-II promotes cell proliferation and inhibits apoptosis via ERK (88), and up-regulates the expression of collagen-1 and decreases the expression and activity of matrix metalloproteinase-1 (MMP-1) in human umbilical vein endothelial cells (89), leading to the development of atherosclerotic plaque formation. Further, the levels of U-II and UT receptor expression are up-regulated by interferon- $\gamma$ an inflammatory mediator produced by activated $\mathrm{T}$ lymphocytes found within the atherosclerotic plaque (42). Hypoxia also increased U-II expression in endothelial cells and VSMCs in rat pulmonary arteries (90). However, neither perfusion pressure nor shear stress induced U-II expression in bovine pulmonary artery endothelial cells (91). These data support an autocrine/paracrine role for the increased U-II by endothelial cells in inducing proliferation of VSMCs in the intima and probably their migration from the media.

Interestingly, we demonstrated recently that U-II accelerates the formation of human macrophage-derived foam cells by up-regulation of acyl-coenzyme A:cholesterol acyltransferase-1 (ACAT-1), which is an intracellular enzyme located in the rough endoplasmic reticulum and converts intracellular free cholesterol into cholesterol ester for storage in lipid droplets, but not by the effect of U-II on scavenger receptor class A (SR-A) (18) or adenosine triphosphate-binding cassette transporter A-1 (ABCA-1) (our unpublished data). U-IIinduced ACAT-1 up-regulation is mediated via the UT receptor/Gq protein/c-Src/PKC/ERK and RhoA/ROCK pathways in human monocyte-derived macrophages (18) (Fig. 3). U-II significantly increases ACAT-1 protein levels by 2.5 -fold as well as the ACAT-1 mRNA levels and ACAT enzyme activity. Our previous studies indicated that ACAT- 1 expression is up-regulated by transforming growth factor- $\beta_{1}$ ( $\sim 2$-fold $)$, serotonin $(\sim 2$-fold $)$, and angiotensin II $(\sim 2$-fold $)$, but not endothelin-1 ( $\sim 1.4$-fold), and is down-regulated by adiponectin $(18,92-94)$. The at least 2-fold increases in ACAT-1 expression induced by these vasoactive agents may be significant cellular events that accelerate the formation of human macrophage-derived foam cells. It is possible that U-II induces monocyte-endothelial cell adhesion via the activation of RhoA/ROCK, as U-II activates RhoA/ROCK in human monocyte-derived macrophages.

U-II also induces VSMC proliferation via the UT receptor followed by various intracellular signal transduction mechanisms, such as Gq protein, protein tyrosine kinases of epidermal growth factor (EGF) receptor and c-Src, focal adhesion kinase (FAK), PKC, ERK, and the RhoA/ROCK-related pathways $(19,20,69,95)$ (Fig. 3). We have shown that U-II exerts a synergistic effect with highly oxidized LDL, mildly oxidized LDL, lysophosphatidylcholine, hydrogen peroxide, or serotonin in inducing rabbit aortic VSMC proliferation (19, 20). U-II shows synergistic interactions with mildly oxidized LDL in inducing rabbit aortic VSMC proliferation at the highest rate among vasoactive $\mathrm{G}$ protein agonists (endothelin1 , angiotensin II, serotonin, and thromboxane- $\left.\mathrm{A}_{2}\right)(11,19)$. In addition, U-II activates nicotinamide adenine dinucleotide phosphate (NADPH) oxidase, a major cellular source of superoxide, and plasminogen activator inhibitor-1 (PAI-1) in human pulmonary VSMCs (96), leading to the progression of atherosclerotic plaque. Activation of cell adhesion-mediated integrin signaling also plays a crucial role in U-II-induced phosphorylation involving ERK, in which FAK is not 
required as a signaling molecule (97). However, U-II activates FAK phosphorylation in VSMCs (95), probably leading to integrin-extracellular matrix interactions (Fig. 3).

Little information is available regarding the effects of U-II on platelet aggregation. Shoji et al. (98) showed that U-II at concentrations up to $10 \mu \mathrm{mol} / \mathrm{l}$ had no significant effects on platelet aggregation or P-selectin (CD62P) activation by using platelets from healthy volunteers. Bousette et al. (38) showed that the level of U-II expression is relatively low, but the level of UT receptor expression is undetectable in human platelets.

\section{U-II and Coronary Artery Disease}

Plasma levels of U-II increased in accordance with the severity of coronary artery disease (46) (Table 1). Plasma U-II concentrations are significantly higher in patients with triplevessel disease than in healthy volunteers or patients with single- or double-vessel disease (46). In addition, plasma U-II concentrations are increased in patients with restenosis after percutaneous transluminal coronary angioplasty (99).

Human U-II-like immunoreactivity was originally reported in the human vasculature with diffuse staining in cardiac myocytes and intense staining in the macrophage- and VSMC-rich regions of human coronary atherosclerotic plaque (32). Recently, Hassan and colleagues (100) reported that U-II is expressed in endothelial cells, foam cells, and myointimal and medial VSMCs of atherosclerotic human coronary arteries. Maguire and Davenport (36) reported the expression of U-II in endothelial cells of the human epicardial coronary artery as well as intramyocardial vessels with diameters typical of resistance arteries $(60-120 \mu \mathrm{m})$ but not in cardiac myocytes or VSMCs. However, in atherosclerotic lesions of the human coronary arteries, U-II was detected within the region of infiltrating macrophages of the plaque but not contractile VSMCs of media or proliferated VSMCs of the thickened intima $(36,37)$. Double immunostaining with anti-U-II antibody and an anti-CD68 antibody specific for macrophages demonstrated the co-localization of U-II and macrophages, suggesting that U-II may be produced mainly by these cells (37). In human atherosclerotic coronary artery lesions, the additional macrophage source of U-II may contribute not only to overall vasoconstriction in the diseased vasculature, but also to progression of the lesion (36). While, UT receptors are present in VSMCs throughout the human coronary artery tree, from large epicardial to small resistance arteries, and mediate vasoconstriction (57). However, there are no differences in the UT receptor density on the medial VSMCs between human normal and atherosclerotic coronary arteries (101). Bousette and colleagues (38) showed recently that lymphocytes are by far the largest producers of U-II, whereas monocytes and macrophages are the major cell types that express UT receptors, with relatively little expression in foam cells or lymphocytes in human leukocytes.

U-II contracted rat isolated left anterior descending coro- nary arteries with endothelium, and this contractile response was significantly enhanced by removal of the endothelium (55). U-II also can induce potent vasorelaxation in coronary arteries dependent on endothelial function, and this effect is mediated by the formation of endogenous $\mathrm{NO}, \mathrm{PGI}_{2}$, prostaglandin $\mathrm{E}_{2}$, or endothelium-derived hyperpolarizing factor $(36,54,70)$ (Fig. 2). In patients with significant endothelial dysfunction, there is in vitro evidence that U-II may cause vasoconstriction or inadequate vasodilation leading to myocardial ischemia $(59,102)$. Ischemia-reperfusion in Langendorff preparations decreases coronary flow, and this is exacerbated by administration of U-II during the reperfusion phase (103). Douglas et al. (43) showed that U-II is expressed at high levels in the surviving cardiomyocytes of the infarction and border zones of the myocardium. Further, U-II is expressed in myofibroblasts and macrophages of patients with coronary artery disease (43). U-II induces the expression of mRNAs encoding procollagen $\left(\alpha_{1}[\mathrm{I}], \alpha_{1}[\mathrm{III}]\right)$ and fibronectin in rat neonatal cardiac fibroblasts (104), and induces cardiac hypertrophy by up-regulation of ANP and BNP (105) and the inflammatory cytokines, such as interleukin- 6 and interleukin-1 $\beta$, after UT receptor overexpression $(41,43)$. These findings suggest that U-II may have hemodynamic actions and play a role in the remodeling processes that occur after myocardial infarction.

U-II is a coronary vasospastic agent in a number of different species, including dogs (56), monkeys (17), and humans (37), although it exerts both constrictor and vasodilatory effects in normal rats depending on the endothelial cell status (55). This is important as it implies that endothelial cell dysfunction should shift the balance toward vasoconstriction and away from vasodilation within the coronary tree. In addition, the role of U-II in acute coronary syndrome remains unclear. Joyal et al. (106) showed that plasma levels of U-II were lower in patients with acute coronary syndrome than in those with stable coronary artery disease and healthy controls. This result was contrary to their expectations. After all, they hypothesized that an acutely damaged endothelium led its UII release reduction in acute coronary syndrome. Further studies are needed to assess the changes in plasma U-II levels following the onset of acute coronary syndrome.

\section{Therapeutics}

The development of UT receptor antagonists may provide a useful research tool as well as novel treatment regimens for cardiovascular diseases. Several UT receptor antagonists significantly inhibited the vasoconstrictor effect of U-II (107). Among these antagonists, the peptide BIM-23127 ( $\beta$-[2naphthyl]-D-Ala-cyclic(Cys-Tyr-D-Trp-Orn-Val-Cys)- $\beta$-[2naphthyl]-D-Ala-amide) and non-peptides S-6716 (1-[3-carbamimidoyl-benzyl]-4-methyl-1H-indole-2-carboxylic acid [naphthalene-1-ylmethyl]amide) and ACT-058362 (1-[2-(4benzyl-4-hydroxy-piperidin-1-yl)-ethyl]-3-(2-methyl-quinolin-4-yl)-urea sulfate salt) blocked human UT receptors (108, 
109). BIM-23127 inhibited U-II-induced cardiomyocyte hypertrophy (41). Treatment with ACT-058362 increased insulin release from the pancreas and slowed the increase in glycemia and serum lipids, and delayed the development of proteinuria and renal damage by increasing renal blood flow in streptozotocin-induced diabetic rats (110). Our recent study (18) indicated that the selective UT receptor antagonist peptide urantide (H-Asp-cyclo[Pen-Phe-D-Trp-Orn-TyrCys]-Val-OH) (111) and non-peptide 4-aminoquinoline (1benzyl-6-bromo-2,3-dihydro-1H-pyrrolo[2,3-b]quinolin-4ylamine) (112) significantly inhibit U-I-induced ACAT-1 upregulation in cultured human monocyte-derived macrophages, which may prevent the formation of macrophagederived foam cells followed by atherosclerotic plaque. Treatment with SB-611812 (2,6-dichloro- $N$-(4-chloro-3-\{[2(dimethylamino)ethyl]oxy\} phenyl)-4-(trifluoromethyl)benzene sulfonamide), a selective non-peptide UT receptor antagonist, significantly reduced intimal thickening (restenosis) following balloon angioplasty in rat carotid arteries (85). In rats with congestive heart failure induced by ligating the left coronary artery, treatment with SB-611812 at $30 \mathrm{mg} / \mathrm{kg} /$ day for 8 weeks significantly reduced the mortality by $75 \%$, and significantly improved cardiac function and cardiac remodeling (113). This drug also significantly reduced cardiomyocyte hypertrophy and collagen production (113). These findings suggest that selective UT receptor antagonists may be useful in the preventive care of cardiovascular diseases.

\section{Protective Role of U-II in Cardiovascular Disease}

To date, most research into the role of U-II in human systems has focused on the cardiovascular effects of the peptide. Data suggest that U-II has potential as a modulator of vascular tone and cardiac function and that alterations in the U-II system may contribute to, or result from, cardiovascular disorders. It is unclear at present whether the predominant action of U-II in human disease will be protective or deleterious. This review must be balanced by the opposite fact that U-II has (transient) coronary vasodilator and vasodepressor (hypotensive) effects on SHR $(54,114,115)$, and an anti-apoptotic effect on human endothelial cells (88). It remains to be elucidated whether U-II plays a compensatory protective role as a coronary vasodilator under pathophysiological conditions such as ischemic heart disease. Further studies using several selective UT receptor antagonists or urotensin converting enzyme inhibitors, and knockout or transgenic animals are required to investigate the protective role of U-II in coronary events.

\section{Conclusions}

The recent cloning of the gene encoding U-II has facilitated research into this molecule. Our results, together with those of other studies, suggest that U-II is atherogenic and may play a crucial role in the etiology of hypertension, diabetic mellitus, hyperlipidemia, and obesity. These findings provide an increased understanding of the potential molecular mechanisms by which these factors promote the development of atherosclerosis, and hence coronary artery disease - this is the well-established concept of the metabolic syndrome (12). Taken together, the results of a number of studies suggest that the U-II/UT receptor system may be a promising new therapeutic target in U-II-mediated atherosclerotic coronary events in hypertension and the metabolic syndrome.

\section{Acknowledgements}

The authors thank Dr. Toshiaki Suguro, First Department of Internal Medicine, Showa University School of Medicine, and Dr. Yoshiyuki Ban, Division of Internal Medicine, Showa University Karasuyama Hospital, for their collaboration in collecting the unpublished data described here. Their studies were approved by the institutional ethical board of Showa University School of Medicine.

\section{References}

1. Wilson PW, D'Agostino RB, Levy D, Belanger AM, Silbershatz H, Kannel WB: Prediction of coronary heart disease using risk factor categories. Circulation 1998; 97: 1837 1847.

2. Psaty BM, Furberg CD, Kuller LH, et al: Association between blood pressure level and the risk of myocardial infarction, stroke, and total mortality: the cardiovascular health study. Arch Intern Med 2001; 161: 1183-1192.

3. Domanski M, Mitchell G, Pfeffer M, et al: Pulse pressure and cardiovascular disease-related mortality: follow-up study of the Multiple Risk Factor Intervention Trial (MRFIT). JAMA 2002; 287: 2677-2683.

4. Mancia G, Parati G, Hennig M, et al: Relation between blood pressure variability and carotid artery damage in hypertension: baseline data from the European Lacidipine Study on Atherosclerosis (ELSA). J Hypertens 2001; 19: 1981-1989.

5. Chobanian AV, Lichtenstein AH, Nilakhe V, Haudenschild CC, Drago R, Nickerson C: Influence of hypertension on aortic atherosclerosis in the Watanabe rabbit. Hypertension 1989; 14: 203-209.

6. Tropea BI, Huie P, Cooke JP, Tsao PS, Sibley RK, Zarins CK: Hypertension-enhanced monocyte adhesion in experimental atherosclerosis. J Vasc Surg 1996; 23: 596-605.

7. Furumoto T, Saito N, Dong J, Mikami T, Fujii S, Kitabatake A: Association of cardiovascular risk factors and endothelial dysfunction in Japanese hypertensive patients: implications for early atherosclerosis. Hypertens Res 2002; 25: 475-480.

8. Curmi PA, Juan L, Tedgui A: Effect of transmural pressure on low density lipoprotein and albumin transport and distribution across the intact arterial wall. Circ Res 1990; 66: 1692-1702.

9. Santilli SM, Fiegel VD, Knighton DR: Changes in the aortic wall oxygen tensions of hypertensive rabbits. Hypertension 
1992; 19: 33-39.

10. Crawford DW, Blankenhorn DH: Arterial wall oxygenation, oxyradicals, and atherosclerosis. Atherosclerosis 1991; 89: 97-108.

11. Watanabe T, Pakala R, Katagiri T, Benedict CR: Antioxidant $N$-acetylcysteine inhibits vasoactive agents-potentiated mitogenic effect of mildly oxidized LDL on vascular smooth muscle cells. Hypertens Res 2002; 25: 311-314.

12. Takeuchi H, Saitoh S, Takagi S, et al: Metabolic syndrome and cardiac disease in Japanese men: applicability of the concept of metabolic syndrome defined by the National Cholesterol Education Program-Adult Treatment Panel III to Japanese men - the Tanno and Sobetsu Study. Hypertens Res 2005; 28: 203-208.

13. Griendling KK, Sorescu D, Ushio-Fukai M: NAD(P)H oxidase: role in cardiovascular biology and disease. Circ Res 2000; 86: 494-501.

14. Hozawa A, Ebihara S, Ohmori K, et al: Increased plasma 8isoprostane levels in hypertensive subjects: the Tsurugaya project. Hypertens Res 2004; 27: 557-561.

15. Maggi E, Marchesi E, Ravetta V, Martignoni A, Finardi G, Bellomo G: Presence of autoantibodies against oxidatively modified low-density lipoprotein in essential hypertension: a biochemical signature of an enhanced in vivo low-density lipoprotein oxidation. J Hypertens 1995; 13: 129-138.

16. Frostegard J, Wu R, Lemne C, Thulin T, Witztum JL, Faire $\mathrm{U}$ : Circulating oxidized low-density lipoprotein is increased in hypertension. Clin Sci (Lond) 2003; 105: 615-620.

17. Ames RS, Sarau HM, Douglas SA, et al: Human urotensin II is a potent vasoconstrictor and agonist for the orphan receptor GPR14. Nature 1999; 401: 282-286.

18. Watanabe T, Suguro T, Miyazaki A, et al: Human urotensin II accelerates foam cell formation in human monocytederived macrophages. Hypertension 2005; 46: 738-744.

19. Watanabe T, Pakala R, Katagiri T, Benedict CR: Synergistic effect of urotensin II with mildly oxidized LDL on DNA synthesis in vascular smooth muscle cells. Circulation 2001; 104: 16-18.

20. Watanabe T, Pakala R, Katagiri T, Benedict CR: Synergistic effect of urotensin II with serotonin on vascular smooth muscle cell proliferation. J Hypertens 2001; 19: 2191-2196.

21. Watanabe T, Kanome T, Suguro T, Miyazaki A: Human urotensin II and metabolic syndrome. Vascular Disease Prevention 2006; 3: 91-98.

22. Cheung BM, Leung R, Man YB, Wong LY: Plasma concentration of urotensin II is raised in hypertension. J Hypertens 2004; 22: 1341-1344.

23. Matsushita M, Shichiri M, Imai T, et al: Co-expression of urotensin II and its receptor (GPR14) in human cardiovascular and renal tissues. J Hypertens 2001; 19: 2185-2190.

24. Totsune K, Takahashi K, Arihara Z, Sone M, Ito S, Murakami O: Increased plasma urotensin II levels in patients with diabetes mellitus. Clin Sci (Lond) 2003; 104: $1-5$.

25. Totsune K, Takahashi K, Arihara Z, et al: Elevated plasma levels of immunoreactive urotensin II and its increased urinary excretion in patients with type 2 diabetes mellitus: association with progress of diabetic nephropathy. Peptides 2004; 25: 1809-1814.

26. Suzuki S, Wenyi Z, Hirai M, et al: Genetic variations at urotensin II and urotensin II receptor genes and risk of type 2 diabetes mellitus in Japaneses. Peptides 2004; 25: $1803-$ 1808.

27. Langham RG, Kelly DJ, Gow RM, et al: Increased expression of urotensin II and urotensin II receptor in human diabetic nephrophathy. Am J Kidney Dis 2004; 44: 826-831.

28. Takahashi K: Translational medicine in fish-derived peptides: from fish endocrinology to human physiology and diseases. Endocr J 2004; 51: 1-17.

29. Watson AMD, Lambert GW, Smith KJ, May CN: Urotensin II acts centrally to increase epinephrine and ACTH release and cause potent inotropic and chronotropic actions. Hypertension 2003; 42: 373-379.

30. Silvestre RA, Egido EM, Hernandez R, et al: Urotensin-II is present in pancreatic extracts and inhibits insulin release in the perfused rat pancreas. Eur $J$ Endocrinol 2004; 151: 803-809.

31. Sheridan MA, Plisetskaya EM, Bern HA, Gorbman A: Effects of somatostatin-25 and urotensin II on lipid and carbohydrate metabolism of coho salmon, Oncorhynchus kisutch. Gen Comp Endocrinol 1987; 66: 405-414.

32. Douglas SA, Ohlstein EH: Human urotensin-II, the most potent mammalian vasoconstrictor identified to date, as a therapeutic target for the management of cardiovascular disease. Trends Cardiovasc Med 2000; 10: 229-237.

33. Russell FD, Kearns P, Toth I, Molenaar P: Urotensin-IIconverting enzyme activity of furin and trypsin in human cells in vitro. J Pharmacol Exp Ther 2004; 310: 209-214.

34. Douglas SA, Ohlstein EH: Urotensin receptors, in Girdalstone D (ed): The IUPHAR Compendium of Receptor Characterization and Classification. London, IUPHAR Media, 2000, pp 365-372.

35. Protopopov A, Kashuba V, Podowski R, et al: Assignment of the GPR14 gene coding for the G-protein-coupled receptor 14 to human chromosome 17q25.3 by fluorescent in situ hybridization. Cytogenet Cell Genet 2000; 88: 312-313.

36. Maguire JJ, Davenport AP: Is urotensin-II the new endothelin? Br J Pharmacol 2002; 137: 579-588.

37. Maguire JJ, Kuc RE, Wiley KE, Kleinz MJ, Davenport AP: Cellular distribution of immunoreactive urotensin-II in human tissues with evidence of increased expression in atherosclerosis and a greater constrictor response of small compared to large coronary arteries. Peptides 2004; 25: 1767-1774.

38. Bousette N, Patel L, Douglas SA, Ohlstein EH, Giaid A: Increased expression of urotensin II and its cognate receptor GPR14 in atherosclerotic lesions of the human aorta. Atherosclerosis 2004; 176: 117-123.

39. Richards AM, Charles C: Urotensin II in the cardiovascular system. Peptides 2004; 25: 1795-1802.

40. Russell FD, Meyers D, Galbraith AJ, et al: Elevated plasma levels of human urotensin-II immunoreactivity in congestive heart failure. Am J Physiol Heart Circ Physiol 2003; 285: $1576-1581$.

41. Johns DG, Ao Z, Naselsky D, et al: Urotensin-II-mediated cardiomyocyte hypertrophy: effect of receptor antagonism and role of inflammatory mediators. Naunyn Schmiedebergs Arch Pharmacol 2004; 370: 238-250.

42. Birker-Robaczewska M, Boukhadra C, Studer R, Mueller C, Binkert C, Nayler O: The expression of urotensin II 
receptor (U2R) is up-regulated by interferon- $\gamma$. $J$ Recept Signal Transduct Res 2003; 23: 289-305.

43. Douglas SA, Tayara L, Ohlstein EH, Halawa N, Giaid A: Congestive heart failure and expression of myocardial urotensin II. Lancet 2002; 359: 1990-1997.

44. Mallamaci F, Cutrupi S, Pizzini P, Tripepi G, Zoccali C: Urotensin II in end-stage renal disease: an inverse correlate of sympathetic function and cardiac natriuretic peptides. $J$ Nephrol 2005; 18: 727-732.

45. Charles CJ, Rademaker MT, Richards AM, Yandle TG: Urotensin II: evidence for cardiac, hepatic and renal production. Peptides 2005; 26: 2211-2214.

46. Heringlake M, Kox $\mathrm{T}$, Uzun $\mathrm{O}$, et al: The relationship between urotensin II plasma immunoreactivity and left ventricular filling pressures in coronary artery disease. Regul Pept 2004; 121: 129-136.

47. Lapp H, Boerrigter G, Costello-Boerrigter LC, et al: Elevated plasma human urotensin-II-like immunoreactivity in ischemic cardiomyopathy. Int J Cardiol 2004; 94: 93-97.

48. Ng LL, Loke I, O'Brien RJ, Squire IB, Davies JE: Plasma urotensin in human systolic heart failure. Circulation 2002; 106: $2877-2880$.

49. Totsune K, Takahashi K, Arihara Z, et al: Role of urotensin II in patients on dialysis. Lancet 2001; 358: 810-811.

50. Heller J, Schepke M, Neef M, Woitas R, Rabe C, Sauerbruch T: Increased urotensin II plasma levels in patients with cirrhosis and portal hypertension. J Hepatol 2002; 37: 767-772.

51. Balat O, Aksoy F, Kutlar I, et al: Increased plasma levels of Urotensin-II in preeclampsia-eclampsia: a new mediator in pathogenesis? Eur J Obstet Gynecol Reprod Biol 2005; 120: 33-38.

52. Gruson D, Rousseau MF, Ahn SA, van Linden, Ketelslegers JM: Circulating urotensin II levels in moderate to severe congestive heart failure: its relations with myocardial function and well established neurohormonal markers. Peptide 2006, in press.

53. Gibson A: Complex effects on Gillichthys urotensin II on rat aortic strips. Br J Pharmacol 1987; 91: 205-212.

54. Ishihata A, Ogaki T, Aita T, Katano Y: Role of prostaglandins in urotensin II-induced vasodilatation in the coronary arteries of aged rats. Eur J Pharmacol 2005; 523: 119-126.

55. Bottrill FE, Douglas SA, Hiley CR, White R: Human urotensin-II is an endothelium-dependent vasodilator in rat small arteries. Br J Pharmacol 2000; 130: 1865-1870.

56. Douglas SA, Sulpizio AC, Piercy V, et al: Differential vasoconstrictor activity of human urotensin-II in vascular tissue isolated from the rat, mouse, dog, pig, marmoset and cynomolgus monkey. Br J Pharmacol 2000; 131: 12621274.

57. Maguire JJ, Kuc RE, Davenport AP: Orphan-receptor ligand human urotensin II: receptor localization in human tissues and comparison of vasoconstrictor responses with endothelin-1. Br J Pharmacol 2000; 131: 441-446.

58. Behm DJ, Harrison SM, Douglas SA, et al: Deletion of the UT receptor gene results in the selective loss of urotensin-II contractile activity in aortae isolated from UT receptor knockout mice. Br J Pharmacol 2003; 139: 464-472.

59. Russell FD, Molenaar P, O'Brien DM: Cardiostimulant effects of urotensin-II in human heart in vitro. Br J Pharma- col 2001; 132: 5-9.

60. Bennett RT, Jones RD, Morice AH, Smith CFC, Cowen ME: Vasoconstrictive effects of endothelin-1, endothelin-3, and urotensin II in isolated perfused human lungs and isolated human pulmonary arteries. Thorax 2004; 59: 401-407.

61. Hillier C, Berry C, Petrie MC, et al: Effects of urotensin II in human arteries and veins of varying caliber. Circulation 2001; 103: 1378-1381.

62. Stirrat A, Gallagher M, Douglas SA, et al: Potent vasodilator responses to human urotensin-II in human pulmonary and abdominal resistance arteries. Am J Physiol Heart Circ Physiol 2001; 280: H925-H928.

63. MacLean MR, Alexander D, Douglas SA, et al: Contractile responses to human urotensin-II in rat and human pulmonary arteries: effect of endothelial factors and chronic hypoxia in the rat. Br J Pharmacol 2000; 130: 201-204.

64. Russell FD: Emerging roles of urotensin-II in cardiovascular disease. Pharmacol Ther 2004; 103: 223-243.

65. Giebing G, Tolle M, Jurgensen J, et al: Arrestin-independent internalization and recycling of the urotensin receptor contribute to long-lasting urotensin II-mediated vasoconstriction. Circ Res 2005; 97: 707-715.

66. Opgaard OS, Nothacker HP, Ehlert FJ, Krause DN: Human urotensin II mediates vasoconstriction via an increase in inositol phosphates. Eur J Pharmacol 2000; 406: 265-271.

67. Tasaki K, Hori M, Ozaki H, Karaki H, Wakabayashi I: Mechanism of human urotensin II-induced contraction in rat aorta. J Pharmacol Sci 2004; 94: 376-383.

68. Rossowski WJ, Cheng BL, Taylor JE, Datta R, Coy DH: Human urotensin II-induced aorta ring contractions are mediated by protein kinase $\mathrm{C}$, tyrosine kinases and Rhokinase: inhibition by somatostatin receptor antagonists. Eur J Pharmacol 2002; 438: 159-170.

69. Sauzeau V, Mellionnec EL, Bertoglio J, Scalbert E, Pacaud P, Loirand G: Human urotensin II-induced contraction and arterial smooth muscle cell proliferation are mediated by RhoA and Rho-kinase. Circ Res 2001; 88: 1102-1104.

70. Gray GA, Jones MR, Sharif I: Human urotensin II increases coronary perfusion pressure in the isolated rat heart: potentiation by nitric oxide synthase and cyclooxygenase inhibition. Life Sci 2001; 69: 175-180.

71. Lin L, Ding WH, Jiang W, et al: Urotensin-II activates Larginine/nitric oxide pathway in isolated rat aortic adventitia. Peptides 2004; 25: 1977-1984.

72. Bohm F, Pernow J: Urotensin II evokes potent vasoconstriction in humans in vivo. Br J Pharmacol 2002; 135: 25 27.

73. Wilkinson IB, Affolter JT, de Haas SL, et al: High plasma concentrations of human urotensin II do not alter local or systemic hemodynamics in man. Cardiovasc Res 2002; 53: 341-347.

74. Affolter JT, Newby DE, Wilkinson IB, Winter MJ, Balment RJ, Webb DJ: No effect on central or peripheral blood pressure of systemic urotensin II infusion in humans. Br J Clin Pharmacol 2002; 54: 617-621.

75. Sondermeijer B, Kompa A, Komesaroff P, Krum H: Effect of exogenous urotensin-II on vascular tone in skin microcirculation of patients with essential hypertension. Am J Hypertens 2005; 18: 1195-1199.

76. Behm DJ, Doe CP, Douglas SA, et al: Urotensin-II: a novel 
systemic hypertensive factor in the cat. Naunyn Schmiedebergs Arch Pharmacol 2004; 369: 274-280.

77. Lin Y, Tsuchihashi T, Matsumura K, Abe I, Iida M: Central cardiovascular action of urotensin II in conscious rats. $J$ Hypertens 2003; 21: 159-165.

78. Lin Y, Tsuchihashi T, Matsumura K, et al: Central cardiovascular action of urotensin II in spontaneously hypertensive rats. Hypertens Res 2003; 26: 839-845.

79. Lu Y, Zou CJ, Huang DW, Tang CS: Cardiovascular effects of urotensin II in different brain areas. Peptides 2002; 23: 1631-1635.

80. Song W, Ashton N, Balment RJ: A radioimmunoassay to detect urotensin II in the plasma of rat models of hypertension. J Physiol 2002; 544: S024 (Abstract).

81. Thompson JP, Watt P, Sanghavi S, Strupish JW, Lambert DG: A comparison of cerebrospinal fluid and plasma urotensin II concentrations in normotensive and hypertensive patients undergoing urological surgery during spinal anesthesia: a pilot study. Anesth Analg 2003; 97: 1501-1503.

82. Rdzanek A, Filipiak KJ, Karpinski G, Grabowski M, Opolski G: Exercise urotensin II dynamics in myocardial infarction survivors with and without hypertension. Int J Cardiol 2005, in press.

83. Liu GQ, Zeng ZP, Li HZ, et al: Expression of urotensin II and G-protein coupled receptor 14 mRNA in human pheochromocytoma tissues. Zhongguo Yi Xue Ke Xue Yuan Xue Bao 2005; 27: 457-460.

84. Yamamoto H, Watanabe T, Miyazaki A, et al: High prevalence of Chlamydia pneumoniae antibodies and increased high-sensitive C-reactive protein in patients with vascular dementia. J Am Geriatr Soc 2005; 53: 583-589.

85. Rakowski E, Hassan GS, Dhanak D, Ohlstein EH, Douglas SA, Giaid A: A role for urotensin II in restenosis following balloon angioplasty: use of a selective UT receptor blocker. J Moll Cell Cardiol 2005; 39: 785-791.

86. Wang ZJ, Shi LB, Xiong ZW, et al: Alteration of vascular urotensin II receptor in mice with apolipoprotein E gene knockout. Peptides 2006; 27: 858-863.

87. Gendron G, Simard B, Gobeil F Jr, Sirois P, D’OrleansJuste P, Regoli D: Human urotensin-II enhances plasma extravasation in specific vascular districts in Wistar rats. Can J Pysiol Pharmacol 2004; 82: 16-21.

88. Shi L, Ding W, Li D, et al: Proliferation and anti-apoptotic effects of human urotensin II on human endothelial cells. Atherosclerosis 2005, in press.

89. Wang H, Mehta JL, Chen K, Zhang X, Li D: Human urotensin II modulates collagen synthesis and the expression of MMP-1 in human endothelial cells. $J$ Cardiovasc Pharmacol 2004; 44: 577-581.

90. Hongfang J, Bailin C, Bin Z, et al: Effects of hydrogen sulfide on hypoxic pulmonary vascular structural remodeling. Life Sci 2006; 78: 1299-1309.

91. Dschietzig T, Richter C, Bartsch C, et al: Flow-induced pressure differentially regulates endothelin-1, urotensin II, adrenomedullin, and relaxin in pulmonary vascular endothelium. Biochem Biophys Res Commun 2001; 289: 245251.

92. Hori M, Miyazaki A, Tamagawa $\mathrm{H}$, et al: Up-regulation of acyl-coenzyme A:cholesterol acyltransferase-1 by transforming growth factor- $\beta 1$ during differentiation of human monocytes into macrophages. Biochem Biophys Res Commun 2004; 320: 501-505.

93. Suguro T, Watanabe T, Miyazaki A, et al: Serotonin acts as an up-regulator of acyl-coenzyme A:cholesterol acyltransferase-1 in human monocyte-macrophages. Atherosclerosis 2005, in press.

94. Furukawa K, Hori M, Miyazaki A, et al: Adiponectin down-regulates acyl-coenzyme A:cholesterol acyltransferase-1 in cultured human monocyte-derived macrophages. Biochem Biophys Res Commun 2004; 317: 831836.

95. Peng X, Yin H, Wang LH, Chai SB, Shu JL, Tang CS: Content and activity of the focal adhesion kinase in cultured vascular smooth muscle cells enhanced by urotensin II. Sheng Li Xue Bao 2000; 52: 455-458.

96. Djordjevic T, BelAiba RS, Bonello S, Pfeilschifter J, Hess $\mathrm{J}$, Gorlach A: Human urotensin II is a novel activator of NADPH oxidase in human pulmonary artery smooth muscle cells. Arterioscler Thromb Vasc Biol 2005; 25: 519-525.

97. Tamura K, Okazaki M, Tamura M, Isozumi K, Tasaki H, Nakashima Y: Urotensin II-induced activation of extracellular signal-regulated kinase in cultured vascular smooth muscle cells: involvement of cell adhesion-mediated integrin signaling. Life Sci 2003; 72: 1049-1060.

98. Shoji M, Yasujima M, Suda T: Effects of urotensin II on platelets. Nippon Rinsho 2004; 62 (Suppl 9): 715-718 (in Japanese).

99. Fang SH, Li ZL, Wu HC, et al: Clinical study of plasma urotensin II in patients with coronary heart disease. $D i Y i$ Jun Yi Da Xue Xue Bao 2004; 24: 563-565.

100. Hassan GS, Douglas SA, Ohlstein EH, Giaid A: Expression of urotensin-II in human coronary atherosclerosis. Peptides 2005; 26: 2464-2472.

101. Katugampola SD, Kuc RE, Maguire JJ, Davenport: G-protein-coupled receptors in human atherosclerosis: comparison of vasoconstrictors (endothelin and thromboxane) with recently de-orphanized (urotensin-II, apelin and ghrelin) receptors. Clin Sci (Lond) 2002; 103: 171S-175S.

102. Paysant J, Rupin A, Simonet S, Fabiani JN, Verbeuren TJ: Comparison of the contractile responses of human coronary bypass grafts and monkey arteries to human urotensin-II. Fundam Clin Pharmacol 2001; 15: 227-231.

103. Zhou P, Wu SY, Yu CF, et al: Effects of urotensin II on isolated rat hearts under normal perfusion and ischemia reperfusion. Acta Physiol Sin 2003; 55: 442-448.

104. Tzanidis A, Hannan RD, Thomas WG, et al: Direct actions of urotensin II on the heart: implications for cardiac fibrosis and hypertrophy. Circ Res 2003; 93: 246-253.

105.Zou Y, Nagai R, Yamazaki T: Urotensin II induces hypertrophic responses in cultured cardiomyocytes from neonatal rats. FEBS Lett 2001; 508: 57-60.

106. Joyal D, Huynh T, Aiyar N, Guida B, Douglas S, Giaid A: Urotensin-II levels in acute coronary syndromes. Int J Cardiol 2006; 108: 31-35.

107. Douglas SA: Human urotensin-II as a novel cardiovascular target: 'heart' of the matter or simply a fishy 'tail'? Curr Opin Pharmacol 2003; 3: 159-167.

108. Herold CL, Behm DJ, Buckley PT, Foley JJ, Douglas SA: The peptidic somatostatin analogs lanreotide, BIM-23127 and BIM-23042 are urotensin-II receptor ligands. Pharma- 
cologist 2002; 44: 170-171.

109. Clozel M, Binkert C, Birker-Robaczewska M, et al: Pharmacology of the urotensin-II receptor antagonist Palosuran (ACT-058362; 1-[2-(4-benzyl-4-hydroxy-piperidin-1-yl)ethyl]-3-(2-methyl-quinolin-4-yl)-urea sulfate salt): first demonstration of a pathophysiological role of the urotensin system. J Pharmacol Exp Ther 2004; 311: 204-212.

110. Clozel M, Hess P, Qiu C, Ding SS, Rey M: The urotensin-II receptor antagonist palosuran improves pancreatic and renal function in diabetic rats. J Pharmacol Exp Ther 2006; 316: 1115-1121.

111. Patacchini R, Santicioli P, Giuliani S, et al: Urantide: an ultrapotent urotensin II antagonist peptide in the rat aorta. Br J Pharmacol 2003; 140: 1155-1158.
112. Dhanak D, Neeb MJ, Douglas SA: Urotensin-II receptor modulators. Annu Rep Med Chem 2003; 38: 99-110.

113. Bousette N, Ohlstein EH, Dhanak D, Douglas SA, Giaid A: Urotensin-II receptor blockade reduces mortality and improves congestive heart failure. Circulation 2005; 112: II-453.

114. Gardiner SM, March JE, Kemp PA, Bennett: Bolus injection of human UII in conscious rats evokes a biphasic haemodynamic response. Br J Pharmacol 2004; 143: 422-430.

115. Gendron G, Gobeil F Jr, Belanger S, Gagnon S, Regoli D, D'Orleans-Juste P: Urotensin II-induced hypotensive responses in Wistar-Kyoto (Wky) and spontaneously hypertensive (Shr) rats. Peptide 2005; 26: 1468-1474. 